\title{
Growth and competitive abilities of the federally endangered Lindera melissifolia and the potentially invasive Brunnichia ovata in varying densities, hydrologic regimes, and light availabilities.
}

\begin{tabular}{|r|l|}
\hline Journal: & Botany \\
\hline Manuscript ID & cjb-2015-0171.R1 \\
\hline Manuscript Type: & Article \\
\hline Date Submitted by the Author: & 04-Dec-2015 \\
\hline Complete List of Authors: & $\begin{array}{l}\text { Hawkins, Tracy; USDA Forest Service, Southern Research Station } \\
\text { Schiff, Nathan; USDA Forest Service, Southern Research Station } \\
\text { Wilson, Alphus; USDA Forest Service, Southern Research Station } \\
\text { Leininger, Theodor; USDA Forest Service, Southern Research Station } \\
\text { Devall, Margaret; USDA Forest Service, Southern Research Station }\end{array}$ \\
\hline Keyword: & $\begin{array}{l}\text { plant competition, endangered species, invasive species, pondberry, } \\
\text { redvine }\end{array}$ \\
\hline & \multicolumn{2}{|l}{} \\
\hline
\end{tabular}


RUNNING HEAD - Lindera melissifolia and Brunnichia ovata

Growth and competitive abilities of the federally endangered Lindera melissifolia and the potentially invasive Brunnichia ovata in varying densities, hydrologic regimes, and light availabilities.

Tracy S. Hawkins ${ }^{1}$, Nathan Schiff ${ }^{2}$, A. Dan Wilson ${ }^{2}$, Theodor D. Leininger ${ }^{2}$, and Margaret S.

Devall

${ }^{1}$ USDA Forest Service, Center for Bottomland Hardwoods Research, Mississippi State, MS

39762

${ }^{2}$ USDA Forest Service, Center for Bottomland Hardwoods Research, Stoneville, MS 38776

Author for correspondence: Tracy S. Hawkins, Box 9681, Mississippi State, MS 39762; (662)

325-2145; fax (662)325-3278; tracyhawkins@,fs.fed.us

Nathan Schiff - P.O. Box 227; Stoneville, MS 38776; nschiff@,fs.fed.us

A. Dan Wilson - P.O. Box 227; Stoneville, MS 38776 ; dwilson@ffs.fed.us

Theodor Leininger - P.O. Box 227; Stoneville, MS 38776 ; tleininger@,fs.fed.us

Margaret Devall - P.O. Box 227; Stoneville, MS 38776; mdevall@ffs.fed.us 


\begin{abstract}
Brunnichia ovata is a native, perennial, woody vine with the potential to become an aggressive competitor of the federally endangered shrub Lindera melissifolia. Our study simulated habitat disturbances to hydrologic regime and light availability that may occur naturally, or through active management practices aimed at ensuring the sustainability of $L$. melissifolia, and determined species responses to these changes. First year plants of $L$. melissifolia and B. ovata were grown at varying densities, received flooded or non-flooded treatments, and $100 \%, 47 \%$, or $21 \%$ light availabilities. For both species, density effects in combination with light availability and flooding regime influenced total biomass accumulation. In response to flooding treatments, $B$. ovata exhibited a high degree of plasticity in biomass allocated between above- and belowground tissues, whereas biomass allocation in L. melissifolia was relatively unaffected. Interspecific competition occurred primarily in non-flooding treatments. Our study highlighted the complexity of the relationship of L. melissifolia and B. ovata functional trait responses to changes in abiotic and biotic factors, and indicated that it will be necessary to consider entire plant community response to mitigate increased competitive interactions and ensure survival of L. melissifolia populations.
\end{abstract}

KEYWORDS: plant competition, endangered species, invasive species, pondberry, redvine 


\section{Introduction}

The Endangered Species Act of 1973 (U.S. Fish and Wildlife Service 1988) contains three principal components. First, it outlines a process for determining whether a species should be listed as threatened or endangered, and second, it provides legal protection of a listed species and its respective habitat. The third component requires development of a recovery plan. This task is generally the responsibility of biologists and/or ecologists appointed by the lead agency (e.g. U.S. Fish and Wildlife Service). The recovery plan must contain estimates of the current size and health of populations of the listed species, analyses of the causes that led to population decrease, and strategies required to promote population recovery (Foin et al. 1998). Criteria for downlisting and/or delisting of the species are also included. Therefore, should a species meet these criteria and downlisting or delisting of the species occurs, this would be a reflection of the success of the recovery plan.

Unfortunately, the outcomes of recovery plans are often less than successful with few species having recovered to the point of downlisting (Reffalt 1988; McMillan and Wilcove 1994). Shortcomings of recovery plans have been attributed to financial and time constraints on research (Foin et al. 1998) and limited availability of information for most listed species (Shemske et al. 1994). Further, if a recovery plan includes active management, we maintain that knowledge of all species within the plant community is necessary to determine how the community as whole will respond to active management strategies. In other words, instead of focusing solely on response by the species of concern, it is also necessary to have inherent understanding of the plant community response as a whole (Jensen and Meyer 2001). In light of this, the objectives of our study are 1) to investigate growth responses of a federally endangered plant species and a potential competitor by simulating disturbance through altered density, 
hydrologic regime, and along a gradient of light availabilities, and 2) to determine if these variables will influence interspecific competitive interactions.

Lindera melissifolia (Walt.) Blume, is a federally endangered (U.S. Fish and Wildlife Service 1986), deciduous, dioecious shrub that grows in periodically flooded forests in the southeastern United States (Radford et al. 1968). Disjunct populations are distributed throughout the Lower Mississippi Alluvial Valley (LMAV; Hawkins et al. 2009a) and Southeastern Coastal Plain (Beckley and Gramling 2013). Although L. melissifolia plants reproduce both sexually (seeds) and asexually (rhizomes), vegetative reproduction appears to be the predominant form of successful reproduction given the lack of seedlings observed in extant populations (Wright 1994; Hawkins et al. 2010). Ramets produced from networks of rhizomes seemingly contribute to $L$. melissifolia populations composed of spatially segregated unisexual colonies. Colony ratios within these populations tend to be male-biased (Hawkins et al. 2009b). Both Wright (1990) and Hawkins et al. (2010) acknowledged a strong presence of Brunnichia ovata within and around $L$. melissifolia colonies in the LMAV and identified the species as having the potential to become an aggressive competitor.

Brunnichia ovata [(Walter) Shinners; Polygonaceae] is a native perennial, deciduous, woody vine distributed in the southern United States from Florida to Texas and north to Kentucky, Missouri, and Oklahoma (Radford et al. 1968). Commonly known as redvine or American buckwheat vine, B. ovata has the potential to become weedy and/or invasive (Southern Weed Science Society 1998), and is becoming increasingly prevalent in poorly drained soils under cultivation (Elmore 1984). Similarly, it is often a component of the groundcover in bottomland hardwood forests in the LMAV (Noble and Murphy 1975; Thompson 1980), and within the proximity of $L$. melissifolia colonies, its spatial presence often exceeds that of other 
competitors in the ground cover (Hawkins et al. 2010). However, aboveground competition between the two species is not evident. In theory, this is due to late winter and early spring flooding which delays emergence of B. ovata (Wright 1990; Hawkins 2010). On the other hand, given its extensive root/rhizome system (Elmore et al. 1989; Shaw and Mack 1991), the potential for belowground competition exists.

\section{Materials and Methods}

Based on results of a prior study investigating growth and intraspecific competitive abilities of Lindera melissifolia (Hawkins et al. 2009b), and given that male-biased colony ratios exist in naturally occurring L. melissifolia populations, male plants were used in our study. These plants originated from micropropagation of stock plants collected from selected bottomland hardwood forests in Sharkey County, MS and Bolivar County, MS (Hawkins et al. 2007). Plants of Brunnichia ovata were propagated from 5 - $8 \mathrm{~cm}$ sections of rhizomes harvested in Bolivar County, MS. To determine initial mean total dry mass for each species prior to transplanting, 20 plants were randomly selected each from L. melissifolia and B. ovata. Plants were harvested, placed in paper bags, dried until desiccated, and weighed to the nearest $0.001 \mathrm{~g}$.

Randomly selected juvenile L. melissifolia of similar size $(0.14 \pm 0.02 \mathrm{~g})$ and B. ovata plants of similar size $(0.12 \pm 0.01 \mathrm{~g})$ were transplanted into $31 \mathrm{~cm}$ (height) x $35 \mathrm{~cm}$ (diameter) pots containing a 2 peat : 1 sand medium supplemented with superphosphate $\left(467 \mathrm{~g} \cdot \mathrm{m}^{-3}\right)$, 10:10:10 (N:P:K, $\left.1130 \mathrm{~g} \cdot \mathrm{m}^{-3}\right)$, and Milorganite ${ }^{\circledR}\left(2267 \mathrm{~g} \cdot \mathrm{m}^{-3}\right)$. Plants were placed in a single circle, $\sim 3 \mathrm{~cm}$ from the edge of the container, with individual plants equidistant from neighboring plants (exception is density $=1$; plant was placed in the center of the container). For densities $>$ 1, and in mixed plantings, species were alternated in the circle. Placement of plants into pots 
followed an addition series design [additive series (Hassel and Comins 1976) + replacement series (de Wit 1960)] which incorporates variation in both total densities and plant ratios. One addition series contained a total of six monocultures (single species at densities of 1, 6, and 9) and three mixtures $\left(3_{\text {L.m. }}: 3_{\text {B.o. }}, 3_{\text {L.m. }}: 6_{\text {B.o. }}\right.$, and $\left.6_{\text {L.m. }}: 3_{\text {B.o. }}\right)$. Plants that died within the first two weeks following transplanting were replaced with plants of comparable size.

Each addition series was placed in random sequence, in a single circle in one of 18 - 1135 $\mathrm{L}$ aquaculture tanks. Tanks were positioned in a climate-controlled greenhouse in a randomized complete block design with three blocks of six tanks each containing an addition series (i.e. 9 pots per tank). Three replicates (one replicate per block) received one of two flooding treatments (no flooding or 21 days of flooding initiated 30 days after transplanting) and one of three light availabilities $(100 \%, 47 \%, 21 \%$,). Light availability was maintained by suspending neutral density shade cloth over and around PVC structures attached to the rim of tanks receiving the $47 \%$ and $21 \%$ light availability treatments. Tanks randomly selected to receive $100 \%$ light availability had the PVC structure attached to the rim without shade cloth. Potting medium was watered to field capacity when not flooded, and during flooding water was maintained $\sim 2.54 \mathrm{~cm}$ above the medium surface. Throughout the study, diurnal temperatures were maintained at 23.0 $\pm 3.0^{\circ} \mathrm{C}$ (day) and $19.0 \pm 2.0^{\circ} \mathrm{C}$ (night). Thermographs were used to monitor temperatures in shade structures and no significant differences were found among shade structures or between shade structures and open tanks. Plants received a $14 \mathrm{hr}$ light:10 hr dark photoperiod. During the light period, plants received artificial light when ambient photosynthetic photon flux density (PPFD) dropped below $300 \mu \mathrm{mol} \cdot \mathrm{m}^{-2} \cdot \mathrm{sec}^{-1}$.

After 8 weeks of growth, water was removed from aquaculture tanks containing addition series that received flooding treatments. All plants were harvested, the roots washed free of soil, 
and each plant separated into roots, leaves (blade + petiole), and stems. Individual structures for each plant were placed in separate paper bags, labeled with the respective plant number, and then oven-dried at $70^{\circ} \mathrm{C}$ until desiccated. Dried plant structures were weighed to the nearest $0.001 \mathrm{~g}$. Final total plant dry weights (i.e. biomass) represented yield (Y). Relative yield (RY) and relative yield total (RYT) were calculated for each species (L.m. = Lindera melissifolia and B.o. = Brunnichia ovata):

$$
\mathrm{RY}_{(L . m . \text { or B.o. })}=\frac{Y m}{Y p} \text { and } \mathrm{RYT}=\mathrm{RY}_{(L . m .)}+\mathrm{RY}_{(\text {B.o. })}
$$

where actual RYs for a species were the quotient derived by dividing total plant biomass of a species grown in mixture $\left(\mathrm{Y}_{m}\right)$ by total plant biomass of that species grown in monoculture $\left(\mathrm{Y}_{p}\right)$. Actual RYs were compared to their expected values $\left(0.50\right.$ for $3_{L . m}: 3_{\text {B.o. }} ; 0.33$ or 0.66 for $3_{L . m}: 6_{\text {B.o. }}$ and $\left.6_{L . m}: 3_{\text {B.o. }}\right)$.

The sum of RYs for L. melissifolia and B. ovata equal actual RYTs, and actual RYTs were compared to the expected value of 1.0 .

\section{Statistical Analyses}

For plants grown in monoculture, three-way analysis of variance (ANOVA) was used to test for main effects and interactions for total plant biomass and percent biomass allocated to roots, stems, and leaves. The square root of biomass allocation percentages were arcsine transformed for analysis. One-way ANOVA was used to compare values within and between treatments and species, and Tukey's (honestly significant difference) test was used as the multiple comparison procedure (SAS Institute, Inc. 2007; $\alpha=0.05$ ).

\section{Results}

When grown in monoculture, total biomass accumulation in Lindera melissifolia plants was influenced independently by flooding and light availability, and the interaction of density, 
flooding and light availability (Table 1). There was no difference in plant total biomass among plant densities within the flooding treatment (Fig. 1A). In the non-flooding treatment, $L$. melissifolia plants grown at a density of one and receiving $47 \%$ light availability accumulated less total biomass than all other plants within this treatment without respect to density or light availability (Fig. 1B). Between flooding treatments, plants grown at a density of one and receiving $21 \%$ light availability in the non-flooding treatment accumulated more total biomass than plants at densities of one and six, and receiving $21 \%$ light availability in the flooding treatment $(p<0.05$; Fig. 1A, B).

Biomass allocated to L. melissifolia roots was affected by all treatments (Table 1; density, flooding, light, and flooding x light). However, biomass allocated to stems was influenced only by flooding regime, and leaf biomass was influenced independently by flooding regime and light availability (Table 1). In high density plantings (density $=6$ and 9$)$, greater biomass was allocated to leaves ( $p \leq 0.0419$; data not shown) and lower biomass allocated to roots $(p<$ 0.0001; data not shown) for plants receiving flooding and $21 \%$ light availability than for those plants in non-flooded conditions and receiving 100\% light availability. This translated into significantly greater aboveground biomass accumulation in flooding treatments with $21 \%$ light availability than in non-flooding treatments at all light availabilities (Table 2). Alternatively, when grown at a density of one, aboveground to belowground biomass ratios in L. melissifolia plants were unaffected by flooding regime (Table 2).

Total biomass in Brunnichia ovata plants grown in monoculture was influenced independently by density, flooding regime, light availability and their interactions (Table 3). In both flooding and non-flooding treatments, total biomass was greatest for plants grown at a density of one and receiving 100\% light availability (Fig. 2A, B). Root biomass was influenced 
independently by all variables and their interactions (exception, density x flooding; Table 3). Further, aboveground to belowground ratios were higher in flooding treatments when compared with those in non-flooding treatments across densities and light availabilities (Table 2). These differences resulted from greater biomass allocation to leaves ( $p \leq 0.0022$; data not shown) and less biomass allocated to roots ( $p \leq 0.0027$; data not shown). We observed adventitious root formation just above the surface of the water in B. ovata plants receiving the flooding treatment. Growth habit was trailing, and plant stems extended over the sides of the aquaculture tanks without shade cloth. Those plants receiving $47 \%$ and $21 \%$ light availability utilized axillary shoot tendrils to climb up the interior of the shade cloth structure.

When grown in mixture, deviations from expected relative yield (RY) occurred primarily in non-flooding treatments. In equal proportions $\left(3_{L . m .}: 3_{B . o}\right)$ and in the non-flooding treatment, actual RY for B. ovata was greater than expected $(p=0.0340)$ in $100 \%$ light availability and less than expected $(p=0.0163)$ at $21 \%$ light availability (Table 4$)$. However, relative yield total (RYT) deviated significantly from the expected value of 1.0 , only in the mixture receiving $21 \%$ light availability $(p=0.0461$; Table 4$)$.

At the proportion of $3_{L . m .}: 6_{\text {B.o. }}$ and in non-flooding conditions actual RY for $L$. melissifolia was lower than expected $(p=0.0119)$ in $100 \%$ light availability, and was greater than expected ( $p=0.0043$ ) for B. ovata at $47 \%$ light availability (Table 4$)$. In neither of these instances did RYT deviate significantly from 1.0.

In mixtures of $6_{L . m}: 3_{\text {B.o. }}$, actual RYs for L. melissifolia were significantly lower than expected in the non-flooding treatment and at $21 \%$ light availability ( $p=0.0255$; Table 4$)$, as well as in the flooding treatment at $100 \%$ light availability $(0.45 \pm 0.02, p=0.0443)$. Actual RYTs did not differ from the expected value of 1.0 . 


\section{Discussion}

Two key components determining species composition in floodplains and periodically flooded bottomland forests are hydrologic regime and light availability (Menges and Waller 1983; Klimas 1988; Gosselink and Lee 1989). Our study simulated changes in these variables that may occur naturally, or through management practices. In turn, our results revealed functional trait responses in both Lindera melissifolia and Brunnichia ovata to short-term flooding occurrence and changes in light availability.

When grown in monoculture, plant size (total biomass accumulation) of L. melissifolia was affected independently by flooding and light, as well as the interaction of density, flooding, and light. Plants receiving the lowest light availability, and growing at a density of one in the flooding treatment accumulated significantly lower total biomass, than those grown at the same density and light availability in the non-flooding treatment. However, in the non-flooding treatment plants grown at a density of nine and receiving $100 \%$ light availability achieved the same total biomass as those at a density one and receiving $21 \%$ light availability. Significantly reduced total biomass for L. melissifolia grown at a density of one in non-flooded conditions and receiving $47 \%$ light availability seems somewhat anomalous, and may be an artifact of this study or genotypic influence born out of random plant selection. However, single $($ density $=1) L$. melissifolia plants grown under these treatments bears repeating to determine if this was a consequence of flooding regime and light availability interaction.

In a similar study investigating growth and competition in juvenile male and female $L$. melissifolia, Hawkins et al. (2009b) found density effects on plant size to be more pronounced, whereby male plants grown at a density of one and receiving a non-flooding treatment, accumulated total biomass almost three times greater than those plants grown at higher densities 
and/or receiving flooding treatments (all plants received 100\% light availability). However, in that study, the plant growth period (21 wk) and flooding durations (30 and 60 days) were longer. Comparatively, this illustrates the dynamic nature of the interactions flood timing and duration, light availability, and plant density as it influences growth response in L. melissifolia.

Lindera melissifolia plants exhibited very slight plasticity in biomass allocated between aboveground tissues (stems and leaves) and belowground tissues (roots) in response to treatments, and any significant differences were observed primarily between flooding and nonflooding treatments. For example, greater biomass was allocated to aboveground tissues only at the higher density plantings in flooded conditions and lowest light availability, than those same densities at all light availabilities in the non-flooding treatment. In contrast, Lockhart et al. (2013) described adult L. melissifolia as displaying a high level of plasticity across a light availability gradient, as well as being relatively unaffected by hydrologic regime. This suggests that functional trait responses of first-year L. melissifolia to abiotic factors may be constrained by ontogeny (Gedroc et al. 1996; Geng et al. 2007; Lockhart et al. 2012).

In contrast to L. melissifolia, plants of B. ovata showed a high degree of plasticity in response to flooded versus non-flooded conditions. In the two highest light availabilities and flooded conditions, B. ovata plants allocated four to seven times more biomass to aboveground tissues than those plants in non-flooded conditions. However, at the lowest light availability and in flooded conditions, aboveground biomass was reduced to only two times that of plants grown in non-flooded conditions. Further, total biomass was affected by all variables independently and through interactions, and was most pronounced when $B$. ovata was grown at a density of one. Given this species plasticity in biomass allocation, morphology (i.e. adventitious roots and 
axillary tendrils), as well as plant size, $B$. ovata plants possess functional traits that promote invasiveness (Claridge and Franklin 2003; van Kleunin et al. 2010).

Plastic responses to resource availability are often linked to competitiveness (Berendse and Elberse 1990). However, the morphological response of B. ovata to flooded conditions and lower light availability was a proportional increase in biomass allocated to aboveground tissues resulting in lengthy vining via axillary tendrils away from flooding and toward higher light availability. In a natural environment this would allow for escape from unsuitable habitat and movement to favorable habitat, and potentially alleviate direct competition with L. melissifolia. On the other hand, increased biomass to belowground tissues in non-flooded conditions and across all light availabilities suggests occupation of suitable habitat, and belowground competition with L. melissifolia may come into play.

Our competition study presented 18 permutations of variables, and when utilizing relative yield (RY) to assess competitive interactions, deviation from expected RY was indicated in six of the 18 interspecific interactions. Of these six, five occurred in non-flooded conditions. When grown in equal proportions with L. melissifolia, and at the highest light availability, actual RY for $B$. ovata exceeded the expected value. This also occurred in the $3_{\text {L.m. }}: 6_{\text {B.o. }}$ mixture grown at 47\% light availability. These results suggest that within the assemblage of variables just described, growth of B. ovata benefited from the interspecific interaction, and L. melissifolia was relatively unaffected. In contrast, actual RYs for L. melissifolia in non-flooding treatments were lower than expected at the highest and lowest light availabilities, and at proportions of $3_{\text {L.m. }}: 6_{\text {B.o }}$ and $6_{\text {L.m. }}: 3_{\text {B.o., }}$ respectively. When grown in monoculture, Brunnichia ovata allocated significantly more biomass to roots in non-flooding treatments which suggests belowground competition may be occurring (Casper and Jackson 1997) in mixed plantings with the same 
treatments. Our use of RY to assess competition illustrates how changes in biotic and abiotic parameters (i.e. hydrologic regime, plant proportion, and light availability) may affect growth and interspecific competitive abilities of both species.

When using relative yield total (RYT) to assess interspecific interactions, competition was indicated only when L. melissifolia and B. ovata were grown in equal proportions, and in non-flooded conditions at $21 \%$ light availability. In this instance, RYT was $<1.0$, and indicates mutual antagonism (Harper 1977). The disparity between RY and RYT in identifying competition is not unusual, and the limitations of using a single index to assess competitive interactions has been the subject of past discussions (e.g. Gibson et al. 1999; Williams and McCarthy 2001; Weigelt and Jolliffe 2003). Our results indicated that RY identified competitive interactions far better than RYT, which is consistent with results found by Williams and McCarthy (2001), and our assessment of competitive interactions was further enhanced by supplementing competition indices with growth analyses.

Based on field research and general observations, Wright (1990) and Hawkins et al. (2010) identified B. ovata as having the potential to become a strong competitor of $L$. melissifolia. However, low light availability typical of bottomland forests (Lhotka and Loewenstein 2006) and periodic flooding during winter and early spring delay B. ovata emergence and seemingly eliminate aboveground competition (Hawkins et al. 2010). On the other hand, our study suggests that in the absence of flooding and with higher light availability, belowground competition may occur and initiate direct interactions with B. ovata that place first year L. melissifolia at a competitive disadvantage.

One of the recommendations in the five year review of the status and recovery of $L$. melissifolia (U.S. Fish and Wildlife Service 2013) is further study of the effects of various types 
of disturbance on the species survivorship and reproduction. Our study has shown that functional trait responses of L. melissifolia to abiotic and biotic changes would depend on numerous factors and their simultaneous interactions, as well as competitor responses. Further, while disturbance may aid survivorship of juvenile plants, it may not have the desired effect on plants at later reproductive growth stages. Although our study simulated disturbance by varying light and hydrologic regime, competitor response was limited to a single potential plant competitor. Indeed, Hawkins et al. (2010) identified 69 plant species growing within $L$. melissifolia colonies located in Mississippi, and thus it is necessary to consider entire plant community response prior to initiating disturbances or employing active management strategies aimed at ensuring survivorship of L. melissifolia populations.

\section{Acknowledgments}

The authors thank Charisse Oberle, Steven Hughes, Amy Abel, and Jim Gruhala for their assistance with data collection, the U.S. Army Corps of Engineers for underwriting the cost of this research, and Drs. Jeffrey Walck and Siti Hidayati for review of an earlier draft of this manuscript.

\section{References}

Beckley, A.C., and Gramling, J.M. 2013. Description and classification of Lindera melissifolia habitat in the southeastern coastal plain. Castanea 78(4): 277-280. doi: 10.2179/13-014.

Berendse, F., and Elberse, W.T. 1990. Competition and nutrient availability in heathland and grassland ecosystems. In Perspectives on plant competition. Edited by J.B. Grace and D. Tilman. Academic Press, San Diego, CA. pp. 93-116.

Casper, B.B., and Jackson, R.B. 1997. Plant competition underground. Annu. Rev. Ecol. Syst. $28: 545-570$. 
Claridge, K., and Franklin S.B. 2003. Compensation and plasticity in an invasive plant species. Biol. Invasions 4(4): 339-347. doi:10.1023/A:1023671006342.

de Wit, C.T. 1960. On competition. Verslagen van Landbouwkundige Onderzoekingen 66: 1-82. Elmore, C.D. 1984. Perennial vines in the delta of Mississippi. Miss. Agric. For. Exp. Stn. Info. Bull. 927.9 pp.

Elmore, C.D., Heatherly, L.G, and Wesley, R.A. 1989. Perennial vine control in multiple cropping systems on a clay soil. Weed Technol. 3(2): 282-287.

Foin, T.C, Riley, S.P.D., Pawley, A.L., Ayres, D.R., Carlsen T.M., Hodum, P.J., and Switzer, P.V. 1998. Improving recovery planning for threatened and endangered species. BioScience 48(3): 177-184.

Gedroc, J.J., McConnaughay, K.D.M, and Coleman, J.S.. 1996. Plasticity in root/shoot partitioning: optimal, ontogenetic, or both? Funct. Ecol. 10(1): 44-50. doi: 10.2307/2390260.

Geng, Y.P., Pan X.Y., Xu, C.Y., Zhang, W.J., Li, B., and Chen, J.K. 2007. Plasticity and ontogenetic drift of biomass allocation in response to above-and below-ground resource availabilities in perennial herbs: a case study of Alternanthera philoxeroides. Ecol. Res. 22(2): 255-260. doi: 10.1007/s11284-006-0017-9.

Gibson, D.J., J. Connolly, D.C. Hartnett, and J.D. Weidenhamer. Designs for greenhouse studies of interactions between plants. J. Ecol. 87: 1-16.

Gosselink, J.G., and Lee, L.L. 1989. Cumulative impact assessment in bottomland hardwood forests. Wetlands 9: 81-174.

Harper, J.L. 1977. Population biology of plants. Academic Press, London.

Hassel, M.P., and Comins, H.N. 1976. Discrete time models for two-species competition. Theor. Popul. Biol. 9(2): 202-221. 
Hawkins, T.S., Schiff, N.M., Gardiner E.S., Leininger, T., Devall, M.S, Wilson, D., Hamel, P., McCown, D.D., and Connor, K. 2007. Micropropagation of the endangered shrub pondberry (Lindera melissifolia [Walt.] Blume). HortScience 42(2): 407-409.

Hawkins, T.S., Skojac, D.S., Lockhart, B.R., Leininger, T.D., Devall, M.S. and Schiff, N. $2009 a$. Bottomland forests in the Lower Mississippi Alluvial Valley associated with the endangered Lindera melissifolia. Castanea 74(2):105-113. doi: 10.2179/07-34.1.

Hawkins, T.S., Schiff, N.M., Leininger, T.D., Gardiner, E.S., Devall, M.S., Hamel, P.B., Wilson, A.D., and Connor, K.F. 2009b. Growth and intraspecific competitive abilities of the dioecious Lindera melissifolia (Lauraceae) in varied flooding regimes. J. Torrey Bot. Soc. 136(1): 91-101. doi: 10.3159/08-RA-049R1.1.

Hawkins, T.S., Skojac D.S., Schiff, N.M., and Leininger, T.D. 2010. Floristic composition and potential competitors in Lindera melissifolia colonies in Mississippi with reference to hydrologic regime. J. Bot. Res. Inst. Texas 4(1): 381-390.

Jensen, K., and Meyer, C. 2001. Effects of light competition and litter on the performance of Viola palustris and on species composition and diversity of an abandoned fen meadow. Plant Ecol. 155(2):169-181. doi: 10.1023/A:1013270628964.

Klimas, C.V. 1988. River regulation effects on floodplain hydrology and ecology. In The ecology and management of wetlands. Volume I: ecology of wetlands. Edited by Hook, D.D., McKee, Jr. W.H., Smith, H.K., [and others] Timber Press, Portland, OR. pp. 40-49.

Lhotka, J.M., and Loewenstein, E.F. 2006. Indirect measures for characterizing light along a gradient of mixed-hardwood riparian forest canopy structures. Forest Ecol. Manag. 226: 310318. doi:10.1016/j.foreco.2006.01.043. 
Lockhart, B.R., Gardiner, E.S, Stautz, T. and Leininger, T.D. 2012. Development and plasticity of endangered shrub Lindera melissifolia (Lauraceae) seedlings under contrasting light regimes. Plant Spec. Biol. 27(1): 30-45. doi: 10.1111/j.1442-1984.2011.00332.x

Lockhart, B.R., Gardiner, E.S., Leininger, T.D, Hamel, P.B., Connor, K.F, Devall, M.S., Schiff, N.M., and Wilson, A.D. 2013. Lindera melissifolia responses to flood durations and light regimes suggest strategies for recovery and conservation. Plant Ecol. 214(7): 893-905. doi: 10.1007/s11258-013-0211-0.

McMillan, M., and Wilcove, D. 1994. Gone but not forgotten: why have species protected by the Endangered Species Act become extinct? Endanger. Species Update 11: 5-6.

Menges, E.S., and Waller, D.M. 1983. Plant strategies in relation to elevation and light in floodplain herbs. The Am. Nat. 122(4): 454-473.

Noble, R.E., and Murphy, P.K. 1975. Short term effects of prolonged backwater flooding on understory vegetation. Castanea 40(3): 228-238.

Radford, A.E., Ahles, H.E., and Bell C.R. 1968. Manual of the vascular flora of the Carolinas. University of North Carolina Press, Chapel Hill.

Reffalt, W.C. 1988. United States listing for endangered species: chronicles of extinction? Endanger. Species Update 5: 10-13.

SAS. 2007. The SAS system for Windows, release V9.2. SAS Institute, Cary, NC.

Schemske, D.W., Husband, B.C., Ruckelshaus, M.H., Goodwillie, C., Parker, I.M., and Bishop, J.G. 1994. Evaluating approaches to the conservation of rare and endangered plants. Ecology 75(3): 584-606. doi: 10.2307/1941718.

Shaw, D.R., and Mack, R.E. 1991. Application timing of herbicides for the control of redvine (Brunnichia ovata). Weed Technol. 5(1): 125-129. 
Southern Weed Science Society. 1998. Weeds of the United States and Canada, CD-ROM. Southern Weed Science Society, Champaign, IL.

Thompson, R.L. 1980. Woody vegetation and floristic affinities of Mingo Wilderness Area, a northern terminus of southern floodplain forest, Missouri. Castanea 45(3): 194-212.

U.S. Fish and Wildlife Service. 1986. Endangered and threatened wildlife and plants: Determination of endangered status for Lindera melissifolia. Federal Register 51: 2749527500.

U.S. Fish and Wildlife Service. 1988. Endangered species act of 1973 as amended through the $100^{\text {th }}$ Congress. U.S. Department of the Interior, Fish and Wildlife Service, Washington, D.C.

U.S. Fish and Wildlife Service. 2013. Pondberry (L. melissifolia) 5-Year Review: Summary and Evaluation. U.S. Fish and Wildlife Service, Vicksburg, MS. Available from http://www.fws.gov/southeast/5yearReviews/5yearreviews/LinderaMelissifolia5yrReview03 072014final.pdf [accessed 24 Jun 2015].

van Kleunen, M., Weber, E., and Fischer, M. 2010. A meta-analysis of trait differences between invasive and non-invasive plant species. Ecol. Letters 13(2): 235-245. doi: 10.1111/j.14610248.2009.01418.x

Weigelt, A., and Jolliffe, P. 2003. Indices of plant competition. J. Ecol. 91(5): 707-720. doi: 10.1046/j.1365-2745.2003.00805.x

Williams, A.C., and McCarthy, B.C. 2001. A new index of interspecific competition for replacement and additive designs. Ecol. Res. 16(1): 29-40. doi: 10.1046/j.14401703.2001.00368.x 
Wright, R.D. 1990. Species biology of Lindera melissifolia (Walt.) Blume. in northeast Arkansas. In Ecosystem management: rare species and significant habitats. Edited by Mitchell, R.S., Sheviah, C.J., and Leopold, D.L. New York State Museum Bulletin 471, Albany, NY. pp. 176-179.

Wright, R.D. 1994. Sex ratio and success, an assessment of Lindera melissifolia in Arkansas. Proc. Arkansas Acad. Sci. 48: 230-233. 
Table 1. Results of three-way analysis of variance (ANOVA, $p=0.05$ ) testing main effects and interactions of density, flooding regime, and light availability on total biomass, and percent biomass allocated to roots, stems, and leaves for first-year plants of Lindera melissifolia grown in monoculture.

\begin{tabular}{|c|c|c|c|c|c|c|c|c|c|}
\hline \multirow[b]{3}{*}{ Source } & \multirow[b]{3}{*}{$\mathrm{df}$} & & & \multicolumn{6}{|c|}{ Biomass Allocation (\%) } \\
\hline & & \multicolumn{2}{|c|}{ Total Biomass } & \multicolumn{2}{|c|}{ Roots } & \multicolumn{2}{|c|}{ Stem } & \multicolumn{2}{|c|}{ Leaves } \\
\hline & & $\mathrm{F}$ & $P$ & $\mathrm{~F}$ & $P$ & $\mathrm{~F}$ & $P$ & $\mathrm{~F}$ & $P$ \\
\hline (1) Density & 2 & 0.14 & 0.8717 & 4.42 & 0.0211 & 0.02 & 0.9791 & 1.98 & 0.1562 \\
\hline (2) Flooding & 1 & 35.31 & $<0.0001$ & 55.44 & $<0.0001$ & 5.63 & 0.0245 & 8.97 & 0.0056 \\
\hline (3) Light & 2 & 3.98 & 0.0298 & 6.93 & 0.0035 & 2.32 & 0.1164 & 7.10 & 0.0031 \\
\hline $1 \times 2$ & 2 & 0.54 & 0.5894 & 0.15 & 0.8585 & 0.35 & 0.7064 & 0.10 & 0.9067 \\
\hline $1 \times 3$ & 4 & 1.75 & 0.1654 & 0.38 & 0.8233 & 1.47 & 0.2357 & 0.61 & 0.6615 \\
\hline $2 \times 3$ & 2 & 0.46 & 0.6381 & 5.36 & 0.0104 & 1.50 & 0.2393 & 0.37 & 0.6952 \\
\hline $1 \times 2 \times 3$ & 4 & 3.13 & 0.0295 & 1.62 & 0.1948 & 0.25 & 0.9071 & 0.82 & 0.5224 \\
\hline
\end{tabular}


Table 2. Aboveground : belowground ratios for monoculture plantings of Lindera melissifolia and Brunnichia ovata grown in flooded and non-flooded conditions, three light availabilities, and at three densities. Means with dissimilar uppercase letters within rows or lowercase letters within columns are significantly different (Tukey, $p<0.05$ )

\begin{tabular}{lcccc}
\hline & Lindera melissifolia & Brunnichia ovata \\
\hline & Density & Density & 6 & 9 \\
\hline
\end{tabular}

\section{$\underline{\text { Flooded }}$}

Light Availability (\%)

\begin{tabular}{|c|c|c|c|c|c|c|}
\hline 100 & $5.12 \pm 0.87^{\mathrm{Aa}}$ & $4.67 \pm 0.36^{\text {Aabc }}$ & $4.54 \pm 0.55^{\mathrm{Aab}}$ & $27.29 \pm 3.60^{\mathrm{Ba}}$ & $21.82 \pm 1.67^{\mathrm{Ba}}$ & $24.96 \pm 2.52^{\mathrm{Ba}}$ \\
\hline 47 & $5.19 \pm 0.49^{\mathrm{Aa}}$ & $5.60 \pm 0.49^{\mathrm{Aab}}$ & $4.85 \pm 0.43^{\mathrm{Aab}}$ & $25.52 \pm 2.11^{\mathrm{Ba}}$ & $24.93 \pm 1.02^{\mathrm{Ba}}$ & $22.74 \pm 0.84^{\mathrm{Ba}}$ \\
\hline 21 & $7.10 \pm 1.00^{\mathrm{Aa}}$ & $6.47 \pm 1.07^{\mathrm{Aa}}$ & $6.45 \pm 0.40^{\mathrm{Aa}}$ & $22.17 \pm 1.17^{\mathrm{Bab}}$ & $21.88 \pm 0.38^{\mathrm{Ba}}$ & $18.49 \pm 1.49^{\mathrm{Ba}}$ \\
\hline & \multicolumn{6}{|c|}{ Non-Flooded } \\
\hline 100 & $4.05 \pm 0.54^{\mathrm{ABa}}$ & $2.92 \pm 0.13^{\mathrm{Ac}}$ & $3.07 \pm 0.41^{\mathrm{ACb}}$ & $6.72 \pm 0.45^{\mathrm{Bc}}$ & $4.50 \pm 0.16^{\mathrm{Cc}}$ & $3.42 \pm 0.34^{\mathrm{ACb}}$ \\
\hline 47 & $3.32 \pm 0.32^{\mathrm{Aa}}$ & $3.73 \pm 0.29^{\mathrm{BCbc}}$ & $3.81 \pm 0.06^{\mathrm{BCb}}$ & $4.05 \pm 0.49^{\mathrm{BCc}}$ & $5.41 \pm 0.37^{\mathrm{BCbc}}$ & $6.46 \pm 1.16^{\mathrm{Bb}}$ \\
\hline 21 & $3.80 \pm 0.48^{\mathrm{Ba}}$ & $3.81 \pm 0.20^{\mathrm{Bbc}}$ & $3.70 \pm 0.20^{\mathrm{Bb}}$ & $15.94 \pm 0.81^{\mathrm{Cb}}$ & $9.55 \pm 0.98^{\mathrm{Ab}}$ & $9.09 \pm 1.17^{\mathrm{Ab}}$ \\
\hline
\end{tabular}


Table 3. Results of three-way analysis of variance (ANOVA, $p=0.05$ ) testing main effects and interactions of density, flooding regime, and light availability on total biomass, and percent biomass allocated to roots, stems, and leaves for first-year plants of Brunnichia ovata grown in monoculture.

\begin{tabular}{|c|c|c|c|c|c|c|c|c|c|}
\hline \multirow[b]{3}{*}{ Source } & \multirow[b]{3}{*}{$\mathrm{df}$} & & & \multicolumn{6}{|c|}{ Biomass Allocation (\%) } \\
\hline & & \multicolumn{2}{|c|}{ Total Biomass } & \multicolumn{2}{|c|}{ Roots } & \multicolumn{2}{|c|}{ Stem } & \multicolumn{2}{|c|}{ Leaves } \\
\hline & & $\mathrm{F}$ & $P$ & $\mathrm{~F}$ & $P$ & $\mathrm{~F}$ & $P$ & $\mathrm{~F}$ & $P$ \\
\hline (1) Density & 2 & 40.19 & $<0.0001$ & 3.92 & 0.0303 & 0.02 & 0.9842 & 0.85 & 0.4389 \\
\hline (2) Flooding & 1 & 20.72 & $<0.0001$ & 425.73 & $<0.0001$ & 9.92 & 0.0036 & 42.33 & $<0.0001$ \\
\hline (3) Light & 2 & 84.48 & $<0.0001$ & 19.71 & $<0.0001$ & 1.13 & 0.3350 & 4.14 & 0.0255 \\
\hline $1 \times 2$ & 2 & 9.65 & 0.0006 & 1.69 & 0.2019 & 4.09 & 0.0264 & 1.53 & 0.2314 \\
\hline $1 \times 3$ & 4 & 22.28 & $<0.0001$ & 5.54 & 0.0018 & 1.54 & 0.2142 & 0.86 & 0.4990 \\
\hline $2 \times 3$ & 2 & 12.50 & 0.0001 & 26.89 & 0.0104 & 0.17 & 0.8456 & 5.07 & 0.0124 \\
\hline $1 \times 2 \times 3$ & 4 & 7.97 & 0.0002 & 5.17 & 0.0026 & 1.67 & 0.1824 & 0.22 & 0.9255 \\
\hline
\end{tabular}


Table 4. Relative yield (RY) and relative yield total (RYT) for Lindera melissifolia (L. m.) and Brunnichia ovata (B.o.) grown in three planting ratios, two densities, and three light availabilities in non-flooded conditions.

\begin{tabular}{|c|c|c|c|c|c|c|}
\hline & & $\mathbf{R Y}_{L . m .}$ & $\mathbf{R Y}_{\text {B.o. }}$ & RYT & & \\
\hline \multirow{9}{*}{$\begin{array}{l}\text { PLANT } \\
\text { RATIO }\end{array}$} & \multirow{3}{*}{$\boldsymbol{3}_{\text {L.m. }}: \boldsymbol{3}_{\text {B.o. }}$} & 0.23 & $0.75^{+}$ & 0.98 & 100 & \multirow{9}{*}{$\begin{array}{c}\text { LIGHT } \\
(\%)\end{array}$} \\
\hline & & 0.74 & 0.49 & 1.20 & 47 & \\
\hline & & 0.30 & $0.31 *$ & $0.66^{*}$ & 21 & \\
\hline & \multirow{3}{*}{$\boldsymbol{3}_{\text {L.m. }}: \mathbf{6}_{\text {B.o. }}$} & $0.09 *$ & 0.80 & 0.89 & 100 & \\
\hline & & 0.22 & $0.94^{\dagger}$ & 1.20 & 47 & \\
\hline & & 0.45 & 0.65 & 1.10 & 21 & \\
\hline & \multirow{3}{*}{$\mathbf{6}_{L . m .}: \mathbf{3}_{\text {B.o. }}$} & 0.60 & 0.42 & 1.02 & 100 & \\
\hline & & 0.50 & 0.40 & 0.90 & 47 & \\
\hline & & $0.29 *$ & 0.45 & 1.06 & 21 & \\
\hline
\end{tabular}

* - actual value significantly lower than expected value $(p<0.05)$

+ - actual value significantly higher than expected value $(p<0.05)$ 


\section{FIGURE CAPTIONS}

FIGURE 1. Mean $( \pm \mathrm{SE})$ total biomass $(\mathrm{g})$ for first-year Lindera melissifolia plants grown at densities of 1, 6, and 9, in flooded (A) and non-flooded (B) treatments, and in light availabilities of $100 \%, 47 \%$, and $21 \%$. Within a hydrogic treatment, values with different lowercase letters are significantly different (Tukey, $p<0.05$ ).

FIGURE 2. Mean ( \pm SE) total biomass (g) for first-year Brunnichia ovata plants grown at densities of 1, 6, and 9, in flooded (A) and non-flooded (B) treatments, and in light availabilities of $100 \%, 47 \%$, and $21 \%$. Within a hydrologic treatment, values with different lowercase letters are significantly different (Tukey, $p<0.05$ ). 


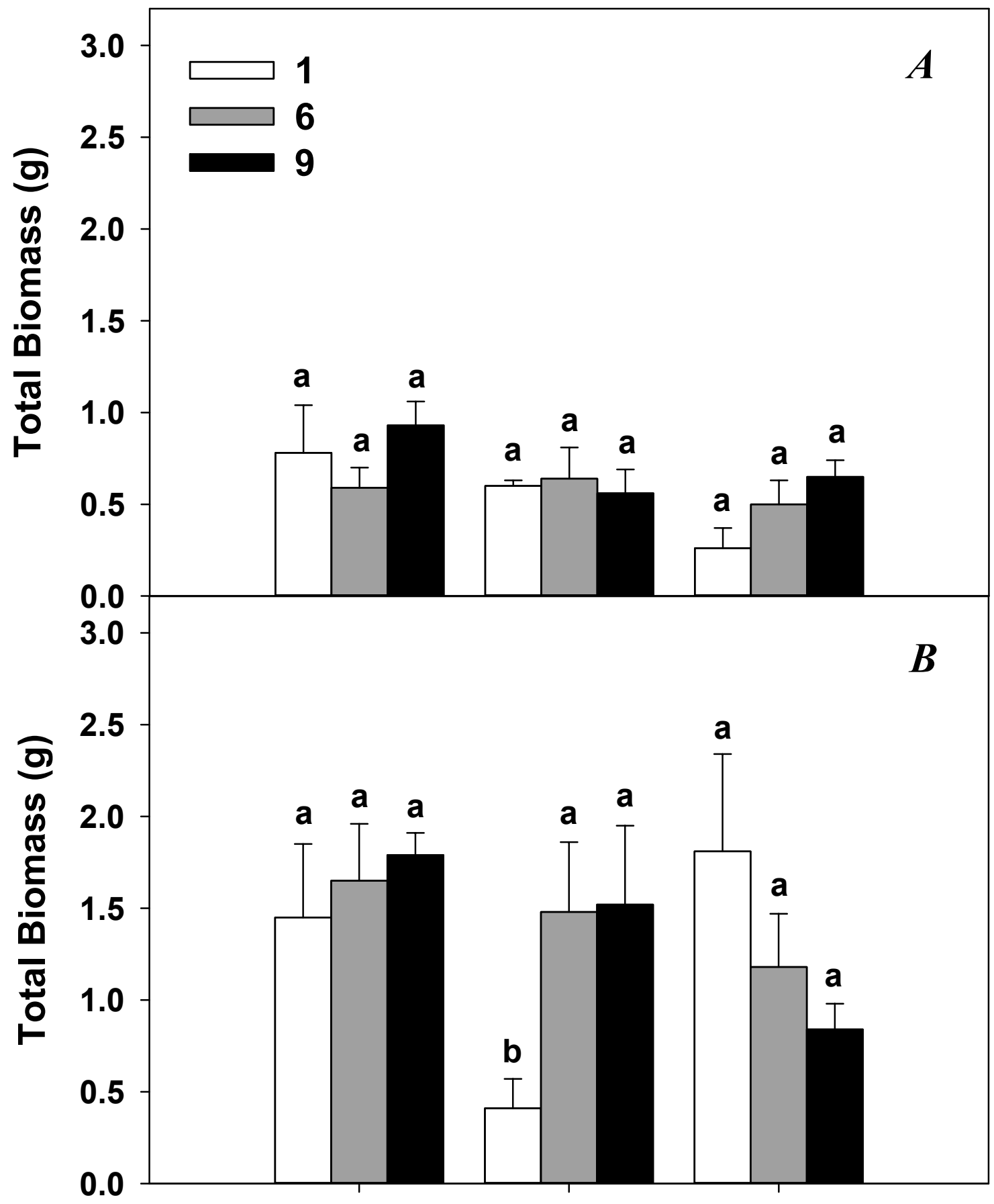

https://m100.manuscriptcenAZI..com/botany-puBS

Light Availability (\%) 


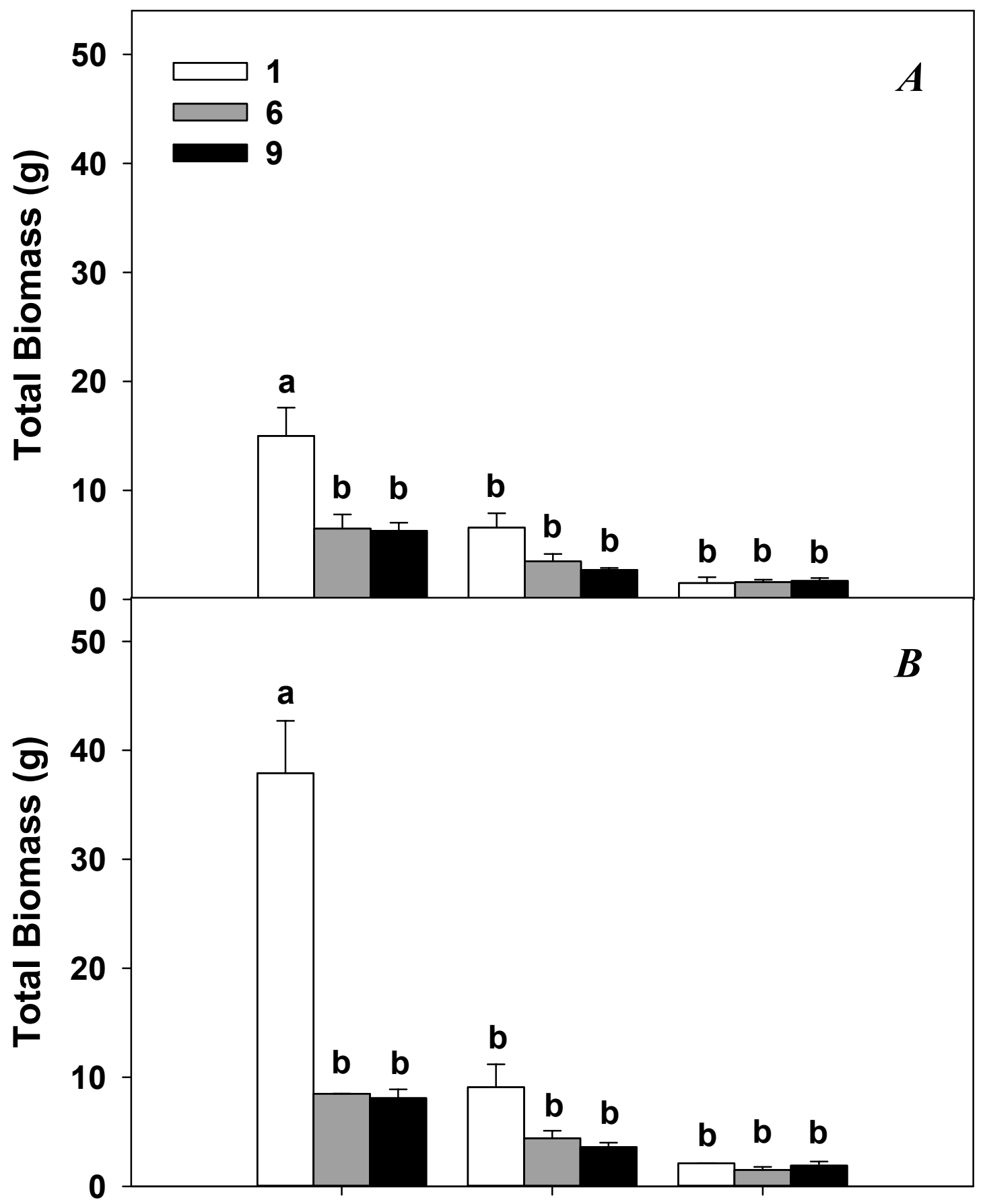

https:00c06.manuscrip/47ntral.com/botany2ðubs 